\title{
Pentecostalism in the Modern World
}

\author{
ADAM STEWART \\ $1^{\text {st }}$ Year, PhD Religious Studies \\ University of Waterloo \\ Waterloo, Ontario
}

\section{Introduction}

On April 9, 1906, a handful of poor African American Methodists gathered for prayer in a small house on 214 Bonnie Brae Street in the city of Los Angeles, California. ${ }^{1}$ Their leader, William Joseph Seymour, was a black Methodist preacher and the son of emancipated slaves. Due to the segregation laws of the Southern states, Seymour's only theological education was a month spent listening to lectures through a half-opened door at a Bible school in Houston, Texas. It was first in this small house and then, a week later, in an abandoned storage building on 312 Azusa Street that the Azusa Street Revival was set in motion when members began to speak in tongues under the influence of the Holy Spirit. ${ }^{2}$ By the middle of the last century, this humble prayer meeting had grown into what Union Theological Seminary professor Henry P. Van Dusen described as "the third force" in Christendom, designating Pentecostalism's importance in comparison with the apostolic church and the Protestant Reformation. ${ }^{3}$ In its short one hundred year history the Pentecostal movement has grown to include over 525 million people around the world, comprising the fastest growing segment of Christianity in the world, second in size only to Roman Catholicism. ${ }^{4}$

\footnotetext{
${ }^{1}$ Frank Bartleman, Azusa Street (South Plainfield, NJ: Bridge Publishing, 1980), 43.

${ }^{2}$ Allan Anderson, An Introduction to Pentecostalism: Global Charismatic Christianity (Cambridge: Cambridge University Press, 2004), 39.

${ }^{3}$ Henry P. Van Dusen, "Third Force in Christendom," Life, 9 June, 1958, 113-124.

${ }^{4}$ David B. Barrett and Todd M. Johnson, “Annual Statistical Table on Global Mission: 2003," International Bulletin of Missionary Research, 27, no. 1 (2003): 24, 25. This number includes in its purview not only Pentecostals but also Charismatics and members of independent churches whose only link with Pentecostalism may be an emphasis on the operation of the "gifts of the Holy Spirit" on a purely phenomenological level. Patrick Johnstone and Jason Mandryk give a more conservative estimate of 345 million Pentecostals as they do not include independent Pentecostal/Charismatic churches in their calculation. David Martin offers an even more cautious estimate of 250
} 
The prolific growth of Pentecostalism throughout the world has led some scholars, such as Allan Anderson, to claim that Pentecostalism is, "flexible and resilient enough to adapt to and be at home with both modernity and its elusive successor, post-modernity." 5 Scholars who make such claims concerning Pentecostalism's future vitality usually point to its success in the developing world where the movement is currently thriving and, without offering substantive proof for their claims, conclude that this trend of growth will continue even once these nations have developed into fully modern urban-industrial societies. The obvious inconsistency with such an explanation is that Pentecostalism's growth in developing or, for a lack of a better term, premodern societies, is used as a basis in order to predict the growth of the movement in what will soon become fully modern societies. Such a prediction fails to account for the effect that the full implications of modernization such as industrialization, urbanization, rationalization, bureaucratization, differentiation, proletarianization, and democratization, will have on individuals' religious decisions. In this paper I argue that Pentecostalism is in fact not adapting to modernity, but rather, continues to function as a movement that primarily assists individuals deal with the socioeconomic consequences normally associated with the transition from premodern to modern society. I will accomplish this by first comparing the origins of Pentecostalism in the United States with that of its most vibrant contemporary expression in Latin America. It is my assertion that if the function of Pentecostalism remains the same in Latin America as it was one hundred years earlier in the United States, then it is misleading for scholars to use the example of the growth of Pentecostalism in the developing world in order to predict its adaptation to modern society. Secondly, I will briefly examine the state of

million Pentecostals as by his own admission he applies a much more selective criteria. See Patrick Johnstone and Jason Mandryk, Operation World: $21^{\text {st }}$ Century Edition (Carlisle: Paternoster Press, 2001), 3, 21; David Martin, Pentecostalism: The World Their Parish (Oxford: Blackwell, 2002), 1.

5 Allan Anderson, 285. 
Pentecostalism in the two very different modern contexts of Canada and the United States. I will argue that the decline of Pentecostalism in Canada, as well as in other modern nations such as those of Western Europe and South Korea, confirms the claim that Pentecostalism has not yet adapted to the needs of a modern constituency. Finally, I will conclude by attempting to assuage the critiques of those who would use the fact that Pentecostalism remains a viable movement in the United States as evidence for the movement's adaptation to modernity. I propose that while the United States is certainly one of the most modern nations in the world that it is simultaneously home to the largest underclass of working poor in the Western world, which serves as a near stable constituency for American Pentecostalism that is not found in any other modern Western state.

\section{American Pentecostal Origins}

Pentecostalism emerged at a time of major social and economic change in the United States. As a result of advances in science and technology, the period between 1865 and 1920 saw the rapid industrialization and urbanization of American society. The impact of these changes was further intensified by the catalyst of the American Civil War. This Gilded Age ${ }^{6}$ of American history was distinctively marked by the confluence of economic advancement and social dislocation. ${ }^{7}$ Following the Civil War millions of African Americans and white ruralagrarians from the Southern states left their farms for better paying jobs in the cities. ${ }^{8}$ Also during this time America initiated mass immigration in order to provide the necessary labour for

\footnotetext{
${ }^{6}$ The term Gilded Age was coined by Mark Twain's cynical novel of the same name in 1873 and came to mean that period of most rapid industrialization in America following the Civil War and continuing until just after the First World War. See Mark Twain and Charles Dudley Warner, The Gilded Age: A Tale of To-day (Hartford: American Publishing Company, 1873).

${ }^{7}$ Rebecca Edwards, New Spirits: Americans in the Gilded Age, 1865-1905 (New York: Oxford University Press, 2006).

${ }^{8}$ Jon Butler, Grant Wacker and Randall Balmer, Religion in American Life: A Short History (New York: Oxford University Press, 2003), 315.
} 
the burgeoning manufacturing sector. ${ }^{9}$ As a result of these changing economic and demographic trends, between 1860 and 1900 the population of the United States grew by nearly two and half times, while the urban population grew by nearly five times. ${ }^{10}$

This rapid industrialization and urbanization resulted in the creation of a new industrial proletariat. The working poor, comprised mostly of the unskilled labourers from the massive rural-urban migration and immigration, formed the bottom rung of the labour force. ${ }^{11}$ The working poor came from a variety of racial, religious, and regional backgrounds and were often African Americans, white rural agrarians from Appalachia and the Ozarks, and immigrants from Southern and Eastern Europe and Latin America. ${ }^{12}$ The social dislocation, economic hardship, deplorable living conditions, and demoralizing factory work resulted in alienation and a general malaise among millions of American migrants and foreign immigrants. Of course, not all of the new industrial proletariat decided to become Pentecostals. What distinguished those who did join the Pentecostal movement from those who did not was a strong sense of emotive traditional religiosity among the former, which Grant Wacker describes as, "Pentecostal's distinctive understanding of the human encounter with the divine."13

Regardless of their varied racial, religious, and regional backgrounds, early American Pentecostals held the common conviction that religion was primarily a matter of the heart. ${ }^{14} \mathrm{~A}$ direct encounter with God was not only possible, but also necessary. ${ }^{15}$ The majority of firstgeneration Pentecostals were heirs of Methodist Holiness teachings, which placed a heavy

\footnotetext{
${ }^{9}$ Sean Dennis Cashman, America in the Gilded Age (New York: New York University Press, 1988), 103.

${ }^{10}$ Robert G. Barrows, "Urbanizing America," in The Gilded Age: Essays on the Origins of Modern America, ed. Charles W. Calhoun, (Wilmington, DE: SR Books, 1996), 93-95.

${ }^{11}$ Edwards, 62-71.

${ }^{12}$ Robert Mapes Anderson, Vision of the Disinherited: The Making of American Pentecostalism (New York: Oxford University Press, 1979), 225, 226.

${ }^{13}$ Grant Wacker, Heaven Below: Early Pentecostals and American Culture (Cambridge, MA: Harvard University Press, 2001), 10.

${ }^{14}$ Robert Anderson, 228.

${ }^{15}$ Wacker, 12.
} 
emphasis on spiritual rebirth and moral living forged during the Great Awakenings. ${ }^{16}$ There were some early Pentecostals who had no exposure to the Methodist Holiness Movement, but they quickly adopted the emotive traditional Pentecostal impulse. Whether from Methodist Holiness, other Protestant denominations that emphasized emotional and revivalistic elements, or syncretic forms of Roman Catholicism, the majority of early Pentecostals came from religious groups that already contained elements of emotive spirituality. ${ }^{17}$

Prior to the Civil War and the Industrial Revolution, one driving force behind much of American Protestantism was the concept of the establishment of the biblical millennium in America. ${ }^{18}$ The more established liberal Protestant denominations strove to usher in the kingdom of God largely through the renewal of American social institutions. This program was the result of their understanding of holiness and Christian responsibility modeled after Charles Finney, who emphasized the salvation and renewal of American society. ${ }^{19}$ The conservative Protestant denominations attempted to achieve this aim by focusing on the renewal of the individual. The conservative Protestant emphasis on the salvation of the individual as opposed to social intervention was due to their understanding of holiness and Christian responsibility modeled after Charles Wesley, who expressly emphasized the salvation and renewal of the soul. $^{20}$

With the advent of the social and economic changes of the latter nineteenth century, liberal Protestantism responded with the Social Gospel, an attempt to transform oppressive

\footnotetext{
${ }^{16}$ Randall Balmer and Lauren F. Winner, Protestantism in America (New York: Columbia University Press, 2002), 43.

${ }^{17}$ Robert Anderson, 228.

${ }^{18}$ Balmer and Winner, 19.

${ }^{19}$ Mark A. Noll, A History of Christianity in the United States and Canada (Grand Rapids: William B. Eerdmans Publishing Company, 1991), 176; Timothy L. Smith, Revivalism and Social Reform (New York: Harper and Row, 1965), 103-113.

${ }^{20}$ Harold Lindstrom, Wesley and Sanctification (London: Epworth, 1956); Vinson Synan, The Holiness Pentecostal Tradition: Charismatic Movements in the Twentieth Century (Grand Rapids: William B. Eerdmans Publishing Co., 1997), 1-21.
} 
American social institutions by mostly middle and upper class Protestants. ${ }^{21}$ Conservative Protestantism on the other hand did not attempt to mount the same kind of pragmatic response to the devastating conditions of American society. While the liberal Protestant concept of the kingdom of God was predicated on human intervention, the conservative Protestant concept anticipated that God would bring about much of the change. As conservative Protestants began to believe that American society was spiraling into further decay, doubts arose whether such a supernatural transformation of society was ever going to happen. As a result, a strong concept of apocalypticism developed within conservative Protestantism and was subsequently incorporated into early Pentecostalism. Conservative Protestants began to realize that American society looked nothing like their imagined kingdom of God, and so God would have to destroy existing society, creating a new kingdom on earth. Pentecostals rejected the liberal Protestant attempt to renew society, instead believing that God alone was able to solve their problems through the apocalyptic destruction and subsequent recreation of the earth. As a result of this conception of society, those things that normally prevented the working poor from ameliorating their social and economic situations such as language barriers, lack of education, and unfamiliarity with American social institutions, were further exacerbated among Pentecostals. Since Pentecostals viewed participation in such things as labour unions, social lodges, and political parties as worldly, ${ }^{22}$ they did not respond to their situation primarily through socioeconomic intervention, but rather the development of a religious community and system of belief which explained their place in the social order.

\footnotetext{
${ }^{21}$ Thomas A. Askew and Richard V. Pierard, The American Church Experience: A Concise History (Grand Rapids: Eerdmans, 2004), 147.

${ }^{22}$ Robert Anderson, 229.
} 


\section{Latin American Pentecostal Origins}

Pentecostalism arose in Latin America in the middle of a major social transformation much as it did in the United States. Approximately sixty-five years after the advent of the most rapid industrialization and urbanization in the United States, a similar transformation occurred throughout Latin America, beginning in 1930 and continuing until approximately $1990 .{ }^{23}$ Just as the American Civil War served as the catalyst for the initiation of modernization in the United States, the Great Depression of 1929 fulfilled a similar function in Latin American society. The Depression was a wake-up call to Latin American business elites, convincing them that they could no longer rely on agricultural export for economic growth, that, instead, they needed to reorient their economy towards industrial expansion. ${ }^{24}$

The reorientation from an agricultural export-based economy to an industrial-based economy initiated a mass rural-to-urban migration throughout Latin America. ${ }^{25}$ It also set new immigration patterns in motion in order to meet the demand for labour in the newly developing industrial sector. ${ }^{26}$ These economic and demographic trends inevitably led to major urbanization throughout much of Latin America. In fact, urban growth in Latin America even surpassed that of the United States and England during their respective periods of initial modernization, ${ }^{27}$ resulting in the development of the largest cities in the Western hemisphere. ${ }^{28}$ For instance, between 1950 and 1990 the total population of Venezuela grew by nearly four times, while the

\footnotetext{
${ }^{23}$ Orlandina de Oliveira, "Urban growth and urban social structure in Latin America, 1930-1990," in The Cambridge History of Latin America, vol. VI, Part I, ed. Leslie Bethell (New York: Cambridge University Press, 1994), 253-324.

${ }^{24}$ Victor Blumer-Thomas, "The Latin American economies, 1929-1939" in The Cambridge History of Latin America, vol. VI, Part I, ed. Leslie Bethell (New York: Cambridge University Press, 1994), 65.

${ }^{25}$ There has actually been a fair amount of research conducted that has made direct correlations between the specific reorientation of Latin American economies from nationalistic to international capitalistic economies with the rise of Pentecostalism. See [Cornelia Butler Flora, "Pentecostalism and Development: The Colombian Case," in Perspectives on Pentecostalism: Case Studies from the Caribbean and Latin America, ed. Stephen D. Glazier (Washington, D.C.: University Press of America, 1980), 81-92.

${ }^{26}$ Oliveira, 254.

${ }^{27}$ Ibid., 256.

${ }^{28}$ For instance Mexico City, Sao Paulo, Buenos Aires, Rio de Janeiro, Bogotá, Lima, and Santiago.
} 
urban population grew by over seven and a half times, a much more rapid rate of growth than was experienced in the United States during the Industrial Revolution. ${ }^{29}$

These social and economic transformations resulted in the complex stratification of Latin American society into upper-class elites, middle-class professionals and entrepreneurs, and the clase humilde, or the lower-class proletariat, comprised mainly of unskilled rural migrant and immigrant labourers. ${ }^{30}$ Similar to nineteenth century America, the working poor in Latin America came from extremely diverse backgrounds. The poor came from a multiplicity of traditional native subcultures and from foreign immigration. ${ }^{31}$ Religious orientation was an extremely important factor separating those Latin Americans who became Pentecostal from those who did not. Just as the earliest proponents of American Pentecostalism maintained an emotive traditional understanding of religion, so did Latin American Pentecostal converts. ${ }^{32}$ Many Latin Americans practiced syncretic forms of Roman Catholicism or indigenous forms of religion before becoming Pentecostal. The emotive traditional element of Pentecostal belief, values, and practice, were attractive to many rural-urban migrants to the metropolises of Latin America. $^{33}$

Similar to the working poor in late nineteenth and early twentieth century America, the working poor in Latin America were economically and socially dislocated and not part of the skilled workforce, so they faced considerable difficulty participating in the labour movement or any other social institutions that could help them improve their socioeconomic situations.

\footnotetext{
${ }^{29}$ Oxford Latin American Economic History Database. < http://oxlad.qeh.ox.ac.uk/index.php $>$

${ }^{30}$ Oliveira, 267.

${ }^{31}$ Cristián Parker, Popular Religion and Modernization in Latin America: A Different Logic (Maryknoll, NY: Orbis Books, 1996), 147; Ian Roxborough, "The urban working class and labour movement in Latin America since 1930," in The Cambridge Companion to Latin America, vol. VI, Part II, ed. Leslie Bethell (New York: Cambridge University Press, 1994), 308.

32 José Miguez Bonino, "The Protestant churches in Latin American since 1930," in The Cambridge Companion to Latin America, vol. VI, Part II, ed. Leslie Bethell (New York: Cambridge University Press, 1994), 591.

${ }^{33}$ David Martin, "Evangelical and Charismatic Christianity in Latin America," in Charismatic Christianity as a Global Culture, ed. Karla Poewe (Columbia, SC: University of South Carolina Press, 1994), 75; Parker, $146-148$.
} 
Pentecostalism then became the means for many Latin Americans to respond to their socially and economically problematic situations by resorting to a religious solution that resembled the magical practices of their former syncretic Roman Catholic and indigenous religions. ${ }^{34}$ Latin American Pentecostalism, with its emphasis on the salvation and renewal of the soul and abandonment of society to the providence of God, espoused a Wesleyan understanding of holiness and Christian responsibility. Latin American Pentecostals also inherited a strong sense of apocalypticism encouraging the belief that it was not possible for them to solve the social and economic problems that they currently faced. Only through God's apocalyptic intervention could the world be made right once again. ${ }^{35}$ Because social solutions were largely unavailable and economic solutions mostly unattainable, the communal, ecstatic, and apocalyptic message being preached in the Pentecostal churches appealed to much of the Latin American proletariat.

It becomes immediately apparent that there are four major similarities between the development of Pentecostalism in the United States during 1865 and 1920 and in Latin America between 1930 and 1990. First, most Pentecostals were part of the massive rural-urban migrations that occurred in order to fulfill the need for urban-industrial expansion. Second, a disproportionate number of Pentecostals come from the lowest of the social strata, namely the urban-industrial proletariat. Third, the majority of Pentecostals came from religious traditions that already emphasized emotive religiosity. Fourth, Pentecostals did not respond to their undesirable situations with social or economic activism but rather with a religious solution being Pentecostalism itself. The reason that the developments of American and Latin American Pentecostalism have such striking similarities is because Pentecostalism fulfilled the same primary functions for its adherents in both situations. Regardless of the cultural, linguistic, and

\footnotetext{
${ }^{34}$ Bonino, 591.

${ }^{35}$ Frank Graziano, The Millennial New World (New York: Oxford University Press, 1999).
} 
historical differences between the advent of Pentecostalism in the United States and Latin American, it fulfilled three primary functions in both contexts.

\section{The Functions of Pentecostalism}

\section{A Restored Sense of Community}

Millions of people who migrated from the farms and villages of both the United States and Latin America were used to a pace of life much different from what they experienced in the factories and cities. In rural-agrarian America and Latin America people understood their identity primarily as part of a closely-knit community, and their responsibility was to that community. In these rural communities relationships were cooperative and personal. The social contract between employee and employer was often amiable. Work was personally satisfying and respected in the social order. Women had an important and distinct role in the life of the family and the community, and there were shared values and religion.

In urban-industrial America and Latin America people understood their identity primarily as individuals and one's responsibility was first to him or herself. In these urban societies relationships were competitive and impersonal. The social contract between employee and employer was oftentimes abusive rather than cordial. Factory work was extremely alienating and personally unrewarding. Women merely became another cog on the wheel of industry, and there was a multiplicity of values and religions from which to choose.

It appears as though what Alexis de Tocqueville predicted would happen within American society after his visit in the 1830 s did indeed come to fruition. During his time spent in the United States Tocqueville observed the prevalence of individualism as a result of the formation of a liberal democracy and an egalitarian society, which he predicted that these developments would move people from a commitment to community to individualistic success 
and self-interest. ${ }^{36}$ Pentecostalism could then be seen as helping to ease the transition for many individuals from the ideal types ${ }^{37}$ which Ferdinand Toennies calls Gemeinschaft, the old order of traditional rural-agrarian community, to Gesellschaft, the new order of modern urban-industrial society. ${ }^{38}$ Pentecostal churches were places where people from a wide variety of racial, religious, and regional backgrounds could come together and share in the experience of a closeknit community with ties to their former traditional ways of life. Pentecostal churches became religious ghettos, places of solidarity for those who still valued traditional beliefs, values, practices, and milieu. In the words of Toennies, the Pentecostal churches could be seen as the remnants of traditional cultures that "remain alive and again bring forth the essence and the idea of Gemeinschaft, thus secretly fostering a new culture amidst the decaying one."39

Through the re-establishment of traditional communities, Pentecostal churches ritually facilitated the restitution of traditional Gemeinschaft religiosity and culture. Pentecostal church services allowed adherents to bask in the presence of God and emerge renewed in order to function in an impersonal and oppressive society. For ethnic or racial minorities who formed the lowest end of the industrial proletariat, for labourers who toiled in highly stratified industrial structures, and for women who were treated unfairly in virtually every other arena of their lives, the Pentecostal community provided the experience of being equal. ${ }^{40}$ The earliest Pentecostal leaders preached that the "color line was washed away in the blood," making community and

\footnotetext{
${ }^{36}$ Alexis de Tocqueville, Democracy in America, vol. 2 (New York: Vintage Books, 1945), 104-106.

${ }^{37}$ Max Weber, Basic Concepts in Sociology (New York: The Citadel Press, 1969), 51-55.

${ }^{38}$ Ferdinand Toennies, Community and Society, trans. C.P. Loomis (New York: Harper and Row, [1887] 1963), 65.

${ }^{39}$ Ibid., 231.

${ }^{40}$ R. Laurence Moore, Religious Outsiders and the Making of Americans (New York: Oxford University Press, 1986), 140.

${ }^{41}$ Bartleman, 54.
} 
commensality distinctive features of the Pentecostal churches in both the United States and Latin America. $^{42}$

The Ecstatic Re-enchantment of the World

Modernization also led to the "disenchantment of the world" $" 43$ for many individuals. The process of modernization resulted in the increased rationalization, differentiation, and bureaucratization of life, particularly for the working poor. The proletariat worked six and seven days a week and oftentimes ten or twelve hours a day. ${ }^{44}$ Life in modern urban-industrial societies became increasingly utilitarian, and was for many an iron cage where there was little emphasis, or even time for, religion, mystery, and creativity. ${ }^{45}$ Virtually all aspects of the industrial proletariat's lives were strictly controlled, resulting in an extremely ordered and regimented life that allowed little time for freedom of expression.

Within Pentecostalism ecstatic and other-worldly experiences such as healings, baptism in the Holy Spirit, being slain in the Spirit, exorcising demons, speaking in tongues, and prophecy were a means to re-enchant the world for Pentecostal adherents. Church services and ecstatic practices served as a temporary respite from the iron cage of industrial society and from the social and economic hardships that adherents experienced in their daily-lives. The belief that one could have direct and personal contact with God was a liberating experience for many who were left uprooted and dislocated from many of the personal relationships and interactions of their traditional communities and cultures. The Pentecostal church services and ecstatic practices were not only a means of mental escape and emotional rejuvenation, but they also

\footnotetext{
${ }^{42}$ Cheryl B. Johns, Pentecostal Formation: A Pedagogy Among the Oppressed (Sheffield: Sheffield Academic Press, 1993), 69.

${ }^{43}$ Max Weber, From Max Weber: Essays in Sociology, ed. H. H. Gerth and C. Wright Mills (New York: Oxford University Press, 1958), 155.

${ }^{44}$ Butler, Wacker and Balmer, 315.

${ }^{45}$ Max Weber, The Protestant Ethic and the Spirit of Capitalism, trans. Talcott Parsons (New York: Charles Scribner's Sons, 1958), 181.
} 
provided a place for the proletariat to express themselves physically, an element greatly lacking in the repetitive work of the factories and the crowded city boroughs. Pentecostal churches in both the United States and Latin America became what Rowan Ireland calls "a common folk religion cutting across religious boundaries."46 Pentecostalism provided a common religious expression for a wide variety of people from different religious backgrounds who each valued a direct relationship with the divine that was otherwise absent in the metropolises of the United States and Latin America. In Latin America specifically, Pentecostalism is a re-manifestation of the traditional shamanistic religious culture of rural Roman Catholicism not found in the urban Roman Catholicism of the Latin American cities. ${ }^{47}$

Apocalypticism - Hope for the Future, Purpose for Today

Pentecostal apocalypticism is a symbolic condemnation of the world. In such a worldview culpability solely rests with the sinful, not with Pentecostals. Since Pentecostals believed that the socioeconomic problems of society were a direct result of sin, then the responsibility for restoring society to the correct configuration was exclusively God's. Such a conceptualization of society alleviated Pentecostals of personal responsibility in the transformation of society. This notion resulted in a futuristic orientation among Pentecostals where it was believed that one day all would be made right again. This eschatology did not result in a complete retreat from society. Rather, while the Pentecostal's Wesleyan understanding of holiness and apocalyptic eschatology did prevent them from engaging in direct and intentional social protest such as labour unions and political parties, it actually assisted Pentecostals in increasing their normative societal participation.

\footnotetext{
${ }^{46}$ Rowan Ireland, Kingdoms Come: Religion and Politics in Brazil (Pittsburgh: University of Pittsburgh Press, 1992), 239.

${ }^{47}$ David Stoll, "Introduction: Rethinking Protestantism in Latin America," in Rethinking Protestantism in Latin America, ed. Virginia Garrard-Burnett and David Stoll (Philadelphia: Temple University Press, 1993), 10, 11.
} 
Because salvation of society was beyond Pentecostal's control, believers did not think that it was apostasy to participate in the workforce, thus they invested in the economy and implicitly followed the Protestant work ethic. Simply because Pentecostals believed that God would intervene in human society did not mean that they should abandon the God-given burden of being productive members of society. This eschatology provided both a sense of hope for the future and a willingness to participate in society in the present. Pentecostals sought to escape from an impersonal society into the face-to-face cultures of their churches. Their church services provided the spiritual renewal, confidence, and self-discipline ${ }^{48}$ necessary to survive the social and economic order of the world. ${ }^{49}$ Through this apocalyptic theology, the Pentecostal churches became what Émile Durkheim called "intermediary societies" ${ }^{50}$ providing the restoration of social matrices, the re-enchantment of the world, and the balancing of the Pentecostal's spiritual and pragmatic impulses. ${ }^{51}$ Gemeinschaft oriented churches, ecstatic releases, and an apocalyptic theology, each allowed Pentecostals to temporarily escape from the world and emerge reconciled with the old order, making them once again able to face the rational, differentiated, and unenchanted iron cage of the new order. ${ }^{52}$

\section{Pentecostalism's Inability to Widen its Appeal}

Pentecostalism's basis for appeal has gone largely unchanged from the time of its original manifestation in the United States to its more contemporary expression in Latin America. Pentecostalism continues to assist those most adversely affected by modern industrial society to deal with the infringement of modern values within their daily lives. Latin American

\footnotetext{
${ }^{48}$ Bryan Wilson, Religion in Secular Society (London: Pelican Books, 1969), 43, 210, 211, $219,220$.

${ }^{49}$ Wacker, 13.

${ }^{50}$ Émile Durkheim, Suicide: A Study in Sociology, trans. John A Spaulding and George Simpson (New York: Free Press, 1951), 378-384.

${ }^{51}$ Wacker, 10-14.

${ }^{52}$ S.D. Clark and Richard Niebuhr discuss this phenomenon at more length. See S.D. Clark, Church and Sect in Canada (Toronto: University of Toronto Press, 1948); Richard Niebuhr, The Social Sources of Denominationalism (New York: H. Holt \& Co., 1929).
} 
Pentecostalism is a response to the effect that modern urban-industrial capitalist society is having upon traditional Latin American's social, economic, cultural, and religious lives. Latin Americans continue to participate within the movement as a result of its ability to provide an operational theodicy that is not typically found in competing social, economic, and religious institutions. ${ }^{53}$ The Gemeinschaft-like nature of the Pentecostal community, retreat found in its ecstatic church services and practices, sense of hope in the future and the license to operate in Gesellschaft society, all assist Latin Americans make sense of the world in which they live. ${ }^{54}$

If Latin American Pentecostalism is any indicator of the entire global Pentecostal movement, then there is little evidence that Pentecostalism is capable of adapting to modernity. There are currently over 141 million Pentecostals in Latin America, a greater concentration than anywhere else in the world. ${ }^{55}$ There are several Latin American countries in which the majority is Protestant, of which Pentecostal is the largest single group, when only forty years ago these same countries were almost entirely Roman Catholic. ${ }^{56}$ If current growth rates remain as they currently stand, in only a few short years several Latin American countries will not only have Protestant majorities, but Pentecostal majorities. ${ }^{57}$ For example, in the early 1990s in Rio de Janeiro, Brazil, the fourth largest city in Latin America, sixty-one percent of all current churches were Pentecostal, and in a city where there is an average of one new church registered each day

\footnotetext{
${ }^{53}$ Weber, From Max Weber, 275.

${ }^{54}$ Malcolm B. Hamilton, The Sociology of Religion: Theoretical and Comparative Perspectives (New York: Routledge, 1995), 138.

${ }^{55}$ D,B. Barrett and T.M. Johnson, "Global Statistics," in New International Dictionary of Pentecostal and Charismatic Movements, ed. Stanley M. Burgess and Eduard M. van der Maas (Grand Rapids: Zondervan, 2002), 287.

${ }^{56}$ Judith Chambliss Hoffnagel, "Pentecostalism: A Revolutionary or Conservative Movement?" in Perspectives on Pentecostalism: Case Studies from the Caribbean and Latin America, ed. Stephen D. Glazier (Washington, D.C.: University Press of America, 1980), 111.

${ }^{57}$ Allan Anderson, 63.
} 
of the year, over ninety percent of these new churches were Pentecostal. ${ }^{58}$ As long as Latin America remains in its transitory stages from a developing premodern to a fully developed modern society in which millions of Latin Americans are uprooted and dislocated by the search for work in the cities, then Pentecostalism will have a ready-made constituency from which to draw its membership.

In every nation in which Pentecostalism is currently growing most rapidly, a similar transition is being made, which has resulted in a sizeable demographic of working poor and those who oppose the infringement of modern values upon their societies. In addition to Latin America's 141 million Pentecostals, in Asia there are an estimated 136 million and in Africa 126 million. ${ }^{59}$ This translates into three quarters of the world's Pentecostals being found in nations making the social and economic transition to modernity. However, in fully modernized nations such as Canada, those of Western Europe, and South Korea, Pentecostalism is in serious decline. For example, in 1991 there were an estimated 436,435 Pentecostals in Canada. ${ }^{60}$ Just ten years later in 2001, there were an estimated 369,475 Pentecostals, a decrease of nearly 67,000 or 15 percent, making Pentecostalism the fourth fastest declining religion in Canada. ${ }^{61}$ South Korean Pentecostalism has traditionally been one of the most successful segments of the global Pentecostal movement, at least partially evidenced by its claim to the largest Christian church in

\footnotetext{
${ }^{58}$ Phillip Berryman, Religion in the Megacity: Catholic and Protestant Portraits from Latin America (New York: Orbis, 1996), 26, 42; Paul Freston, "Charismatic Evangelicals in Latin America: Mission and Politics on the Frontiers of Protestant Growth," in Charismatic Christianity: Sociological Perspectives, ed. Stephen Hunt, Malcolm Hamilton and Tony Walker (London: Macmillan Press, 1997), 187.

${ }_{59}^{5}$ David B. Barrett, George T. Kurian and Todd M. Johnson, World Christian Encyclopedia, $2^{\text {nd }}$ ed., vol. 1. (New York: Oxford University Press, 2001), 13-15.

${ }^{60}$ Religions in Canada, Catalogue 93-319 (Ottawa: Statistics Canada, 1993).

${ }^{61}$ Pentecostalism showed the fourth greatest decrease in percentage change with a $15.3 \%$ decrease next only to the Presbyterian Church with a $35.6 \%$ decrease, the Brethren in Christ with a 22\% decrease, and the Salvation Army with a $21.9 \%$ decrease. See [Statistics Canada, $<$ http://www12.statcan.ca/english/census01/products/highlight/Religion/Page.cfm?Lang=E\&Geo=PR\&View=1a\&C ode $=01 \&$ Table $=1 \&$ StartRec $=1 \&$ Sort $=8 \& B 1=$ Canada $\& B 2=1>$.
} 
the world, Yoido Full Gospel Church in Seoul with over 700,000 members. ${ }^{62}$ However, as South Korean society has made the transition from a post-war industrializing society to a fully modern urban-industrial society, Pentecostalism has begun to decline. ${ }^{63}$ Additionally, Pentecostalism has never made any serious penetration into the European continent.

In modern nations where there is a large middle class, a relatively small lower class, and few people who oppose modern values, Pentecostalism is now entering the stages of institutionalization and routinization. Within the Pentecostalism of these modern nations, respectability and a moderate theology is more important than proselytization and a radical theology because the movement is now drawing the majority of its membership from the middle and upper-middle classes to which a sectarian theology has little appeal compared to the disposition of the traditional lower class base of the movement. ${ }^{64}$ Furthermore, because Pentecostalism no longer draws its membership from the lower class, it is now forced to compete with the other mainline Christian denominations for middle-class members. To use Richard Niebuhr's terms, Pentecostalism in modern societies such as Canada has moved from a “Christ against culture" to a "Christ the transformer of culture" position regarding its relationship with the surrounding society. ${ }^{65}$ Pentecostalism is transitioning and maturing from a sect to a denomination, and is experiencing institutional routinization similar to the transformation

\footnotetext{
${ }^{62}$ Allan Anderson, 1.

${ }^{63}$ Ibid., 285.

${ }^{64}$ Ibid., 285; Gordon Franklin, "Jesus is Coming . . . So What?” Testimony, March, 1989: 32; William A. Griffin, “Kingdom Now: New Hope or New Heresy?” Eastern Journal of Practical Theology, 2, no. 1 (1988): 28; Van Johnson, "Jesus is Coming," Eastern Journal of Practical Theology, 3, no. 2 (1989): 25-33; Carl Verge, A Comparison of the Beliefs and Practices of Two Groups of Pentecostal Assemblies of Canada Ministers: Those With a Master's Degree and Those With Only Three Years of Bible College Training (Ph.D. thesis, New York University, 1987); Carl Verge, "Pentecostal Clergy and Higher Education," Eastern Journal of Practical Theology, 2, no. 1 (1988): 44.

${ }^{65}$ H. Richard Niebuhr, Christ and Culture (New York: Harper \& Row, 1951), 45-82, 190-229.
} 
American Methodism underwent during the nineteenth century. ${ }^{66}$ The strong revivalistic, eschatological, and restorational beliefs, which stress the imminent return of Christ, are no longer emphasized throughout much of contemporary Pentecostalism within these modern societies. ${ }^{67}$ As one Canadian Pentecostal theologian explains, the Pentecostal, "progression towards a predominantly middle-to-upper class movement, from a lower-to-middle class one, has resulted in a people who have a greater stake in this world. It is harder to sing Ira Stanphill's 'Mansion Over the Hilltop' with vigour when you already have a mansion on the hilltop." ${ }^{68}$

If the only evidence that was available was that from the developing nations where Pentecostalism is thriving and the developed nations where Pentecostalism is in sharp decline, then the conclusion would be simple: the initial transition from premodern to modern society predicts an increase in Pentecostalism, while the long-term modernization of a society predicts a decrease in Pentecostalism. This was, of course, the standard explanation for the decline of religious sensibilities purported by secularization theorists for much of the twentieth century. ${ }^{69}$ Despite the temptation to adopt such an orderly conceptualization, Pentecostalism continues to grow in the United States, one of the wealthiest and most modern nations in the world, which also has a large middle-class. ${ }^{70}$ Pentecostalism's vitality in the United States appears to call into question the assertion that it is not adapting to modern society. However, I believe that the major reason why Pentecostalism remains viable in the United States while it declines in most other

\footnotetext{
${ }^{66}$ Aaron I. Abel, The Urban Impact on American Protestantism, 1865-1900 (Hamden, CT: Archon, 1962), 5-7; Paul A. Carter, The Spiritual Crisis of the Gilded Age (DeKalb: Northern Illinois University Press, 1971), 39-44; Richard E. Wentz, Religion in the New World: The Shaping of Religious Traditions in the United States (Minneapolis: Fortress Press, 1990), 157-168.

${ }^{67}$ William J. Seymour, "Back to Pentecost," The Apostolic Faith, October, 1906: 3; William J. Seymour, "Signs of His Coming," The Apostolic Faith, February-March, 1907: 6.

${ }^{68}$ Johnson, 25-26.

${ }^{69}$ José Casanova, Public Religions in the Modern World (Chicago: University of Chicago Press, 1994), 17-35.

${ }^{70}$ Barry A. Kosmin and Seymour P. Lachman, One Nation Under God: Religion in Contemporary American Society (New York: Harmony Books, 1993); U.S. Census Bureau, Statistical Abstract of the United States: 2006 $<$ http://www.census.gov/compendia/statab/population/pop.pdf $>$.
} 
modern societies is due to the fact that in no other modern Western state is the disparity between rich and poor greater than it is in the United States. ${ }^{71}$ This disparity has resulted in a massive and arguably permanent underclass of working poor within the United States who on a daily basis face many of the same socioeconomic challenges as the broader citizenry of those nations currently making the transition from premodern to modern society, which has provided American Pentecostalism with a near stable constituency from which to draw its membership. It is these members of American society, the permanently poor, who now desire the community of equals, ecstatic releases, and apocalyptic promises that keeps American Pentecostalism numerically viable in the United States. What this means is that the full modernization of society does not in and of itself result in the decline of Pentecostalism, but rather, it is the shift of the movement from a predominantly lower class to a middle class orientation as well as the decrease of the lower class working poor in society, which both appear to deprive Pentecostalism from its traditional base of adherents. The evidence available from a variety of sources indicates that Pentecostalism is not adapting to modernity, but rather, continues to primarily function as a movement that helps individuals deal with the socioeconomic consequences normally associated with the transition from premodern to modern societies. As long as there continues to be people around the world who are experiencing the transition to modernity, then Pentecostalism will likely remain a viable option for many people to deal with the social and economic consequences of this process. However, in those nations such as Canada, Western Europe, and South Korea, where the process of modernization is largely complete and where the number of working poor is kept relatively low, than Pentecostalism will likely continue to institutionalize and decline.

\footnotetext{
${ }^{71}$ Julian Bond, "Civil Rights Now and Then," in Challenges to Equality: Poverty and Race in America, ed. Chester Hartman (New York: M.E. Sharpe, 2001), 5-7; Dennis Gilbert, The American Class Structure in an Age of Growing Inequality (New York: Sage, 2008); David Cay Johnston, "Richest Are Leaving Even the Rich Far Behind," in Class Matters (New York: Henry Holt and Company, 2005), 82-91; W.J. Wilson, The Truly Disadvantaged: The Inner City, the Underclass, and Public Policy (Chicago: University of Chicago Press, 1987).
} 


\section{Bibliography}

Abel, Aaron I. The Urban Impact on American Protestantism, 1865-1900. Hamden, CT: Archon, 1962.

Anderson, Allan. An Introduction to Pentecostalism: Global Charismatic Christianity. Cambridge: Cambridge University Press, 2004.

Anderson, Robert Mapes. Vision of the Disinherited: The Making of American Pentecostalism. New York: Oxford University Press, 1979.

Askew, Thomas A. and Richard V. Pierard. The American Church Experience: A Concise History. Grand Rapids: Eerdmans, 2004.

Balmer, Randall and Lauren F. Winner, Protestantism in America. New York: Columbia University Press, 2002.

Barrett, David B., George T. Kurian and Todd M. Johnson. World Christian Encyclopedia. $2^{\text {nd }}$ ed., vol. 1. New York: Oxford University Press, 2001.

and Todd M. Johnson, "Annual Statistical Table on Global Mission: 2003," International Bulletin of Missionary Research. 27, no. 1 (2003): 24, 25.

and Todd M. Johnson, "Global Statistics," in New International Dictionary of Pentecostal and Charismatic Movements. Edited by Stanley M. Burgess and Eduard M. van der Maas. Grand Rapids: Zondervan, 2002.

Barrows, Robert G. "Urbanizing America," in The Gilded Age: Essays on the Origins of Modern America. Edited by Charles W. Calhoun. Wilmington, DE: SR Books, 1996.

Bartleman, Frank. Azusa Street. South Plainfield, NJ: Bridge Publishing, [1925] 1980.

Berryman, Phillip. Religion in the Megacity: Catholic and Protestant Portraits from Latin America. New York: Orbis, 1996.

Blumer-Thomas, Victor. "The Latin American economies, 1929-1939" in The Cambridge History of Latin America. vol. VI, Part I. Edited by Leslie Bethell. New York: Cambridge University Press, 1994.

Bond, Julian. "Civil Rights Now and Then," in Challenges to Equality: Poverty and Race in America. Edited by Chester Hartman. New York: M.E. Sharpe, 2001.

Bonino, José Miguez. "The Protestant churches in Latin American since 1930," in The Cambridge Companion to Latin America. vol. VI, Part II. Edited by Leslie Bethell. New York: Cambridge University Press, 1994. 
Butler, Jon, Grant Wacker and Randall Balmer. Religion in American Life: A Short History. New York: Oxford University Press, 2003.

Butler Flora, Cornelia. "Pentecostalism and Development: The Colombian Case," in Perspectives on Pentecostalism: Case Studies from the Caribbean and Latin America. Edited by Stephen D. Glazier. Washington, D.C.: University Press of America, 1980.

Calhoun, Charles W. The Gilded Age: Essays on the Origins of Modern America. Wilmington, DE: SR Books, 1996.

Carter, Paul A. The Spiritual Crisis of the Gilded Age. DeKalb: Northern Illinois University Press, 1971.

Casanova, José. Public Religions in the Modern World. Chicago: University of Chicago Press, 1994.

Cashman, Sean Dennis. America in the Gilded Age. New York: New York University Press, 1988.

Chambliss Hoffnagel, Judith. "Pentecostalism: A Revolutionary or Conservative Movement?" in Perspectives on Pentecostalism: Case Studies from the Caribbean and Latin America. Edited by Stephen D. Glazier. Washington, D.C.: University Press of America, 1980.

Clark, S.D. Church and Sect in Canada. Toronto: University of Toronto Press, 1948.

Durkheim, Émile. Suicide: A Study in Sociology. Translated by John A Spaulding and George Simpson. New York: Free Press, 1951.

Edwards, Rebecca. New Spirits: Americans in the Gilded Age, 1865-1905. New York: Oxford University Press, 2006.

Franklin, Gordon. “Jesus is Coming . . So What?” Testimony, March, 1989: 32.

Freston, Paul. "Charismatic Evangelicals in Latin America: Mission and Politics on the Frontiers of Protestant Growth," in Charismatic Christianity: Sociological Perspectives. Edited by Stephen Hunt, Malcolm Hamilton and Tony Walker. London: Macmillan Press, 1997.

Garrard-Burnett, Virginia. "God Was Already Here When Columbus Arrived: Inculturation Theology and the Mayan Movement in Guatemala," in Resurgent Voices in Latin America: Indigenous Peoples, Political Mobilization, and Religious Change. Edited by Edward L. Cleary and Timothy J. Steigenga. New Brunswick, NJ: Rutgers University Press, 2004.

Gilbert, Dennis. The American Class Structure in an Age of Growing Inequality. New York: Sage, 2008. 
Graziano, Frank. The Millennial New World. New York: Oxford University Press, 1999.

Greeley, Andrew. The Denominational Society. Glenview, IL: Scott, Foresman and Company, 1972.

Griffin, William A. "Kingdom Now: New Hope or New Heresy?" Eastern Journal of Practical Theology. 2, no. 1 (1988): 28.

Hamilton, Malcolm B. The Sociology of Religion: Theoretical and Comparative Perspectives. New York: Routledge, 1995.

Ireland, Rowan. Kingdoms Come: Religion and Politics in Brazil. Pittsburgh: University of Pittsburgh Press, 1992.

Johns, Cheryl B. Pentecostal Formation: A Pedagogy Among the Oppressed. Sheffield: Sheffield Academic Press, 1993.

Johnson, Van. “Jesus is Coming," Eastern Journal of Practical Theology. 3, no. 2 (1989): 25-33.

Johnston, David Cay. "Richest Are Leaving Even the Rich Far Behind," in Class Matters. New York: Henry Holt and Company, 2005.

Johnstone, Patrick and Jason Mandryk, Operation World: $21^{\text {st }}$ Century Edition. Carlisle: Paternoster Press, 2001.

Kosmin, Barry A. and Seymour P. Lachman, One Nation Under God: Religion in Contemporary American Society. New York: Harmony Books, 1993.

Lindstrom, Harold. Wesley and Sanctification. London: Epworth, 1956.

Martin, David. "Evangelical and Charismatic Christianity in Latin America," in Charismatic Christianity as a Global Culture. Edited by Karla Poewe. Columbia, SC: University of South Carolina Press, 1994.

. Pentecostalism: The World Their Parish. Oxford: Blackwell, 2002.

. Tongues of Fire: The Explosion of Protestantism in Latin America. Oxford: Blackwell, 1990.

Moore, R. Laurence. Religious Outsiders and the Making of Americans. New York: Oxford University Press, 1986.

Niebuhr, Richard. Christ and Culture. New York: Harper \& Row, 1951.

. The Social Sources of Denominationalism. New York: H. Holt \& Co., 1929. 
Noll, Mark A. A History of Christianity in the United States and Canada. Grand Rapids: William B. Eerdmans Publishing Company, 1991.

Oliveira, Orlandina de. "Urban growth and urban social structure in Latin America, 1930-1990," in The Cambridge History of Latin America. vol. VI, Part I. Edited by Leslie Bethell. New York: Cambridge University Press, 1994.

Oxford Latin American Economic History Database. < http://oxlad.qeh.ox.ac.uk/index.php>.

Parker, Cristián. Popular Religion and Modernization in Latin America: A Different Logic. Maryknoll, NY: Orbis Books, 1996.

Religions in Canada, Catalogue 93-319. Ottawa: Statistics Canada, 1993.

Roxborough, Ian. "The urban working class and labour movement in Latin America since 1930," in The Cambridge Companion to Latin America. vol. VI, Part II. Edited by Leslie Bethell. New York: Cambridge University Press, 1994.

Seymour, William J. “Back to Pentecost,” The Apostolic Faith. October, 1906: 3.

. "Signs of His Coming," The Apostolic Faith. February-March, 1907: 6.

Smith, Timothy L. Revivalism and Social Reform. New York: Harper and Row, 1965.

Stark, Rodney and Roger Finke. Acts of Faith: Explaining the Human Side of Religion. Berkeley: University of California Press, 2000.

Statistics Canada. $<$ http://www12.statcan.ca/english/census01/products/highlight/Religion/Page.cfm?Lang= $\underline{\mathrm{E} \& \mathrm{Geo}}=\mathrm{PR} \& \mathrm{View}=1 \mathrm{a} \& \mathrm{Code}=01 \&$ Table $=1 \& \mathrm{StartRec}=1 \&$ Sort $=8 \& \mathrm{~B} 1=$ Canada $\& \mathrm{~B} 2=1>$.

Stoll, David. "Introduction: Rethinking Protestantism in Latin America," in Rethinking Protestantism in Latin America. Edited by Virginia Garrard-Burnett and David Stoll. Philadelphia: Temple University Press, 1993.

Synan, Vinson. The Holiness Pentecostal Tradition: Charismatic Movements in the Twentieth Century. Grand Rapids: William B. Eerdmans Publishing Co., 1997.

Tocqueville, Alexis de. Democracy in America. vol. 2. New York: Vintage Books, 1945.

Toennies, Ferdinand. Community and Society. Translated by C.P. Loomis. New York: Harper and Row, [1887] 1963. 
Twain, Mark and Charles Dudley Warner. The Gilded Age: A Tale of To-day. Hartford: American Publishing Company, 1873.

U.S. Census Bureau. Statistical Abstract of the United States: 2006 $<$ http://www.census.gov/compendia/statab/population/pop.pdf $>$.

Van Dusen, Henry P. “Third Force in Christendom,” Life. 9 June, 1958, 113-124.

Verge, Carl. A Comparison of the Beliefs and Practices of Two Groups of Pentecostal Assemblies of Canada Ministers: Those With a Master's Degree and Those With Only Three Years of Bible College Training. Ph.D. thesis, New York University, 1987.

. "Pentecostal Clergy and Higher Education," Eastern Journal of Practical Theology. 2, no. 1 (1988): 44.

Wacker, Grant. Heaven Below: Early Pentecostals and American Culture. Cambridge, MA: Harvard University Press, 2001.

Weber, Max. Basic Concepts in Sociology. New York: The Citadel Press, 1969.

. From Max Weber: Essays in Sociology. Edited by H.H. Gerth and C. Wright Mills. New York: Oxford University Press, 1958.

. The Protestant Ethic and the Spirit of Capitalism. Translated by Talcott Parsons. New York: Charles Scribner's Sons, 1958.

. The Sociology of Religion. Translated by Ephraim Fischoff. Boston: Beacon Press, [1922] 1993.

Wentz, Richard E. Religion in the New World: The Shaping of Religious Traditions in the United States. Minneapolis: Fortress Press, 1990.

Willems, Emilio. "Protestantism and Culture Change in Brazil and Chile," in Religion, Revolution and Reform. Edited by W. D'Antonio and F. Pike. London: Burns and Oates, 1964.

Wilson, Bryan. Religion in Secular Society. London: Pelican Books, 1969.

Wilson, W.J. The Truly Disadvantaged: The Inner City, the Underclass, and Public Policy. Chicago: University of Chicago Press, 1987. 